\title{
WATER INFRASTRUCTURE ASSET MANAGEMENT: A COMPARATIVE ANALYSIS OF THREE URBAN WATER UTILITIES IN SOUTH AFRICA
}

\author{
ELKINGTON SIBUSISO MNGUNI \\ Trans-Caledon Tunnel Authority, Centurion, South Africa
}

\begin{abstract}
Water and sanitation services in South Africa are characterized by both achievements and challenges. Over the past two decades, the government's main focus has been on the eradication of backlogs with respect to access to basic services, including water and sanitation. However, the government has, over the past decade, reprioritised the planning and implementation of water infrastructure asset management (IAM) systems by water services institutions (WSIs). Well-managed and cared for infrastructure ensures economic growth, social development and environmental integrity. This paper presents an appraisal of water and sanitation IAM systems in South Africa's three urban water utilities: the cities of Johannesburg, Ekurhuleni and Tshwane. Aspects analysed and evaluated were the Asset Inventory and Condition Assessment, Level of Service, Critical Assets, Life-Cycle Costing and the Long-Term Funding Strategy. The study found that the three water utilities have well developed IAM strategies and plans in keeping with national legislation. However, they face funding shortages to implement their plans. Skills shortage is another area of concern. Although it is not severe in metropolitan areas, skills development is still an area that requires a special focus by the utilities. The study sought to understand the current state of IAM practices in these key utilities with the aim of adding to the body of knowledge available and to suggest solutions to challenges being experienced.
\end{abstract}

Keywords: water, sanitation, infrastructure, asset management, skills, funding, sustainability.

\section{INTRODUCTION}

Water services are essential to maintain a good quality of life for the citizens and to support sustainable socio-economic growth and environmental well-being.

Statistics South Africa released results that indicated that $16 \%$ of households in the country do not have access to piped potable water (Stats SA [1]). Although the infrastructure is in place to serve the majority of the population, the reliability levels thereof are often low due to poor management, inadequate maintenance and high service delivery costs. This leads to sporadic service delivery protests in communities.

A national investigative study undertaken in 2005 and 2006 by the South African Department of Water Affairs and the Water Research Commission found that:

- $35 \%$ of wastewater treatment plants surveyed required capital investments for upgrades,

- approximately two thirds of the plants were experiencing problems with disinfection of treated sewage, and

- an estimated 105 fully trained and equipped mechanical and electrical maintenance teams were immediately required to prevent further deterioration of valuable infrastructure and equipment (Republic of South Africa [2]).

While the situation may have improved in some municipalities, there is evidence that it has worsened in others, especially in rural districts and smaller municipalities.

In this light, this paper presents findings from a comparative analysis of South Africa's three major urban water utilities: Johannesburg, Ekurhuleni and Tshwane in terms of how 
efficient and effective their strategies are in managing infrastructure assets. The three utilities support the country's economic hub with a high rate of urbanisation and a growing demand for water resources.

The intention of this study was to identify and highlight areas of excellence and areas that require improvement in order to ensure a sustainable future for the citizens served by these utilities. The study focused on the state of water and sanitation infrastructure for the period up to the end of 2016.

\section{EVOLUTION OF INFRASTRUCTURE ASSET MANAGEMENT}

Asset management originated from the financial sector where the economic approach is dominant. IAM was thus originally led by accountants and economists and was first launched in Australia in the late 1980s as a means of preventing the deterioration of valuable public facilities (Alegre and Coelho [3]).

Prof. Penny Burns of the University of Adelaide, Australia, was instrumental in promoting the formalisation of key concepts and principles of IAM (Burns et al. [4]). To date, Australia remains the leader in this field through both industry practice and initiatives by various organisations.

However, over three decades significant progress in IAM has equally been made in many other countries, such as in the USA (US EPA [5]) and the UK (UKWIR [6]). Practically, good examples of leading-edge utility practice can be found in Asia and in Central and Northern Europe, such as in the Netherlands, Germany, Norway and Sweden.

In view of recent developments, scientific developments have been made aimed at supporting pipe rehabilitation prioritisation and decision-making, life-cycle costing, life time assessment and failure forecasting. Alegre and Almeida [7] also observe that from attendance at international conferences focussing on strategic asset management there has been a clear increase in the interest and recognition of this field of knowledge.

In South Africa, water IAM has been recognised as one of the most critical national issues that need to be addressed at all levels of the water value chain. Government's initial focus was on infrastructure backlogs, which remain a huge challenge, and municipalities are at the forefront of government's drive to eradicate all basic services backlogs. However, with the expansion of services, the challenge to effectively operate and maintain infrastructure has been growing in magnitude leading to the development of the Water Services IAM Strategy which highlights the importance of the development and implementation of IAM systems by all WSIs.

The following section describes how IAM is conceptualised in the South African context.

\section{DEFINING IAM}

\subsection{Description of IAM}

IAM is an integrated process of decision-making, planning and control over the acquisition, use, safeguarding and disposal of assets to maximise their service delivery potential and benefits, and to minimise their related risks and costs over their entire life. Thus IAM includes the operation of infrastructure assets, planned maintenance and repair, refurbishment and renewal, as well as the provision for replacement of the infrastructure that has reached the end of its useful life.

\subsection{South African IAM strategies and processes}

In South Africa, IAM encapsulates the following strategies listed below. 
- Takes an organisation-wide perspective and draws upon applicable principles and techniques in the management, engineering, accounting and social sciences, including human resources.

- Has an outcomes focus, such as maximisation of service delivery potential, protection of the ability of the infrastructure networks to deliver services, cost effectiveness and efficiency.

- Confers a custodianship role on the managers of infrastructure and their political leaders being responsible for the lifelong sustainable operation of the infrastructure and for service delivery, not only to current users of the infrastructure, but also to future users.

- Takes into account both consumer expectations, including levels of service, cost of the service, and the legislative environment such as financial and environmental legislation including regulatory regime for drinking water quality (Republic of South Africa [8]).

Fig. 1 summarises the aforesaid process, illustrating the development of a holistic IAM strategy.

\subsection{Legislative framework}

South Africa has progressed well with legislating for IAM in the water services sector and many WSIs deliver infrastructure services reliably, without unscheduled interruption, and
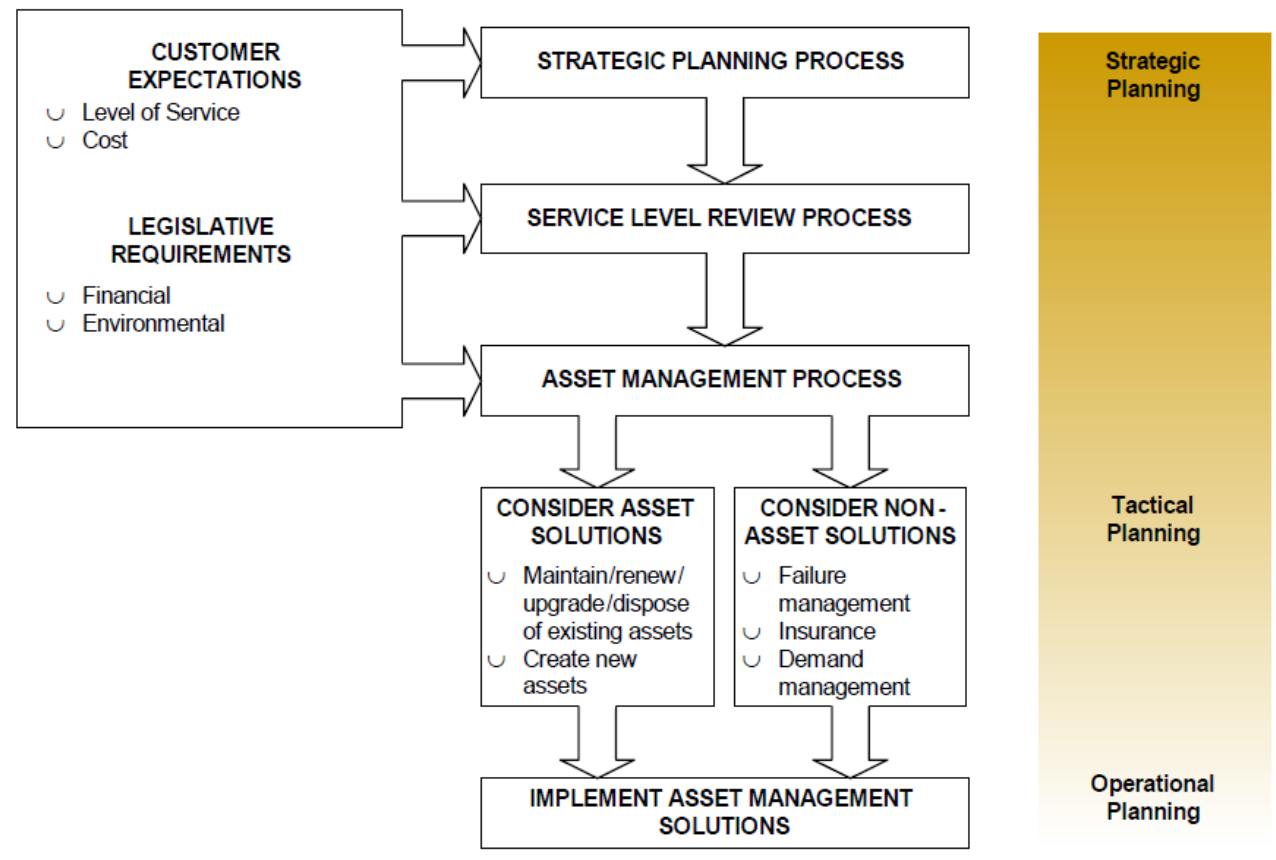

Figure 1: Total asset management process. (Source: International Infrastructure Management Manual.) 
according to specification. These WSIs have skilled staff, and the management of infrastructure assets and services is sufficiently budgeted for. However, where WSIs are not prioritising IAM, where there may be insufficient political will, and where skilled staff and budgets are not available, there has been failure of service provisioning which, in the worst cases, has resulted in total collapse of service provisioning.

A number of national statutes directly or indirectly require effective IAM on the part of municipalities and other WSIs. Specific legislation includes:

- Municipal Structures Act (Act 117 of 1998) which defines municipal functions and powers and relating systems and structures.

- Municipal Systems Act (Act 32 of 2000) which sets out rights, duties, authority and core processes, and, among other things, requires municipalities to prepare Integrated Development Plans (IDPs).

- Municipal Finance Management Act (MFMA) (Act 56 of 2003) which defines financial management and accounting processes. In the case of water boards, which are "national government business enterprises," the equivalent legislation is the Public Finance Management Act (PFMA) (Act 1 of 1999).

- Division of Revenue Act (DoRA) which facilitates the provision of infrastructure grant funding and the equitable share.

The IDP is the principal strategic planning mechanism for municipalities. Compilation of the IDP has to be informed by robust, relevant and holistic information relating to the management of the municipality's infrastructure.

\section{STUDY METHODOLOGY}

The research was conducted through the collection of data from the combination of a desktop qualitative review of literature on IAM, and a workshop with key stakeholders. The literature review focused on the analysis of government publications, the municipalities' water sector development plans, as well as peer-reviewed journals and other publications on IAM. The workshop was attended by thirty-five participants from major cities in South Africa and key government departments, including the National Treasury, Department of Cooperative Governance and Traditional Affairs and the Department of Environmental Affairs. The workshop focused on the state of water and sanitation infrastructure in South Africa's twelve major cities, including the three utilities under study. Each city gave a presentation on their water and sanitation infrastructure development plans, operation and maintenance, as well as related challenges.

The analysis of the IAM systems in the three utilities was based on the following core elements of asset management planning, namely, 1) asset inventory and condition assessment, 2) level of service, 3) critical assets, 4) life cycle costing, 5) long-term funding strategy (New Mexico Environmental Finance Centre [9]).

Components of the IAM systems were analysed using guidelines which were developed for this purpose and shown in Table 1.

\section{STUDY SETTING}

The Cities of Johannesburg, Ekurhuleni and Tshwane, with a combined population of about 12.0 million people, are part of the Gauteng Province which has an integrated cluster of cities, 
Table 1: Guidelines for IAM systems analysis.

\begin{tabular}{|c|c|c|}
\hline $\begin{array}{l}\text { IAM } \\
\text { component }\end{array}$ & Sub-component & Details \\
\hline \multirow{5}{*}{$\begin{array}{l}\text { 1. Asset } \\
\text { inventory and } \\
\text { condition } \\
\text { assessment }\end{array}$} & List of assets & $\begin{array}{l}\text { Pipes, pumps, treatment facilities, } \\
\text { reservoirs, storage tanks, valves, } \\
\text { electrical components, and other related } \\
\text { "hard" infrastructure identified }\end{array}$ \\
\hline & Map of assets & $\begin{array}{l}\text { GIS or similar acceptable electronic } \\
\text { mapping format. }\end{array}$ \\
\hline & Asset condition assessment & $\begin{array}{l}\text { Location, age, composition, size, } \\
\text { condition, design life }\end{array}$ \\
\hline & $\begin{array}{l}\text { Remaining useful life of } \\
\text { assets }\end{array}$ & $\begin{array}{l}\text { Based on design life, service history and } \\
\text { current conditions. }\end{array}$ \\
\hline & Asset replacement value & Repair or Replacement costs \\
\hline $\begin{array}{l}\text { 2. Level of } \\
\text { service (LoS) }\end{array}$ & LoS agreement & $\begin{array}{l}\text { Minimum performance requirements, } \\
\text { e.g. regulations, permit conditions, water } \\
\text { quality standards, assurance of supply, } \\
\text { discharge limits, water loss limits. }\end{array}$ \\
\hline $\begin{array}{l}\text { 3. Critical } \\
\text { assets }\end{array}$ & Criticality analysis & $\begin{array}{l}\text { Assets most critical to the reliable } \\
\text { operation of the utility on a sustainable } \\
\text { basis, based on risk assessment }\end{array}$ \\
\hline \multirow{4}{*}{$\begin{array}{l}\text { 4. Life cycle } \\
\text { costing } \\
\text { resources }\end{array}$} & $\begin{array}{l}\text { Operation and Maintenance } \\
(\mathrm{O \& M}) \text { plan }\end{array}$ & $\begin{array}{l}\text { Plans with schedules and budget } \\
\text { allocations, based on age, risk level, etc. } \\
\text { (routine) }\end{array}$ \\
\hline & O\&M skills & Availability of requisite skills for O\&M \\
\hline & $\begin{array}{l}\text { Repair and replacement } \\
\text { schedule }\end{array}$ & $\begin{array}{l}\text { Schedules reflecting the frequency and } \\
\text { costs of repairs / maintenance or } \\
\text { replacements of components or units } \\
\text { (routine) }\end{array}$ \\
\hline & $\begin{array}{l}\text { Capital Improvement Plan } \\
\text { (CIP) }\end{array}$ & $\begin{array}{l}\text { Project lists (name, description, need, } \\
\text { timelines, costs, funding source, impact } \\
\text { on LoS, etc.) }\end{array}$ \\
\hline \multirow{4}{*}{$\begin{array}{l}\text { 5. Long-term } \\
\text { funding } \\
\text { strategy }\end{array}$} & 5-year financial plan & $\begin{array}{l}\text { Costs and funding sources related to } \\
\text { O\&M and capital projects }\end{array}$ \\
\hline & Rate structure & Tariffs \\
\hline & $\begin{array}{l}\text { Funding strategy for repair } \\
\text { and replace schedule }\end{array}$ & $\begin{array}{l}\text { Adequate and sustainable budgets } \\
\text { allocated for repairs and replacement of } \\
\text { assets (costs and funding sources) }\end{array}$ \\
\hline & Funding strategy for CIP & $\begin{array}{l}\text { Adequate and sustainable budgets } \\
\text { allocated for new assets, renewal or } \\
\text { upgrades to cater for current and future } \\
\text { needs (costs and funding sources) }\end{array}$ \\
\hline
\end{tabular}


towns and urban nodes that together make up the economic heartland of South Africa. The population of Gauteng totals 13.4 million, representing $24.1 \%$ of South Africa's total population of 55.6 million. (Stats SA [1]).

The current population of Johannesburg is estimated at 4.8 million and growing at an average of $3.75 \%$ per annum making it the biggest metro by population size. The City has to ensure that future growth is catered for in order to ensure water security, economic growth through investments in drinking water storage and wastewater treatment capacity if it is to alleviate poverty and unemployment (City of Johannesburg [10]).

The Ekurhuleni Metropolitan Municipality was formed in 2000 from the amalgamation of two regional entities with a legacy of nine towns and seventeen townships. It has a population of approximately 3.4 million people with an average growth rate of $2.47 \%$ per annum, representing $6 \%$ of the country's population and $26 \%$ of Gauteng's population. Service delivery challenges are compounded by the high level of population growth, high levels of poverty and homelessness, and the fragmented nature of previous administrations. Without a single identifiable city centre, Ekurhuleni suffers from the lack of a civic identity (Ekurhuleni Metropolitan Municipality [11]).

The City of Tshwane is home to a range of higher-value functions such as corporate headquarters, financial and business services, manufacturing and major hospitals. The City also accommodates more than 30 Johannesburg Stock Exchange listed companies and is home of national government departments, three universities and hosts 134 foreign embassies and missions, giving it the second highest concentration of diplomatic and foreign missions in the world, after Washington DC in the USA. Tshwane is also the administrative capital of the Republic of South Africa. It has a population of more than 3.1 million residents distributed over seven planning regions that the City instituted to improve service delivery to residents. It is the largest of the three metros in Gauteng by geographical area $\left(6345 \mathrm{~km}^{2}\right)$, making it the third largest municipality in the world. Although this offers opportunities for a vast number of land uses and development, it poses huge challenges in terms of infrastructure development for basic services such as water, sanitation, electricity and social facilities. Due to the vastness of the area, urban sprawl is also a concern and puts a huge burden on infrastructure provision (City of Tshwane [12]).

\section{FINDINGS AND DISCUSSION}

One of the key findings of the study was that all municipalities in South Africa are subject to the laws and regulations as implemented and monitored by various government departments including: Water and Sanitation, Cooperative Governance and Traditional Affairs, as well as the National Treasury. For example, the National Treasury, through its Cities Support Programme, holds the responsibility of ensuring that all metropolitan municipalities comply with the requirements for strategic planning, service level review and asset management processes (Fig. 1). They lead and monitor the Built Environment Performance Planning (BEPP) process and the Municipal Benchmarking exercise in an annual cycle to ensure legislative and regulatory compliance. The three utilities were found to adequately comply with legislation and regulations relating to IAM.

Table 2 summarises the key comparisons among the three utilities' IAM systems and practices at tactical and operational planning levels. Observations and summary of the evaluation outcomes are discussed in the section that follows.

Table 3 provides a high level IAM assessment of the three utilities based on the information collected and recorded in Table 2. 
Table 2: Key IAM comparisons.

\begin{tabular}{|c|c|c|c|c|}
\hline \multirow{2}{*}{$\begin{array}{c}\text { IAM } \\
\text { compo- } \\
\text { nent }\end{array}$} & \multirow{2}{*}{$\begin{array}{c}\text { Sub-compo- } \\
\text { nent }\end{array}$} & \multicolumn{3}{|c|}{ Utility and IAM current status } \\
\hline & & Johannesburg & Ekurhuleni & Tshwane \\
\hline \multirow[t]{5}{*}{$\begin{array}{l}\text { 1. Asset } \\
\text { inventory }\end{array}$} & List of assets & $\begin{array}{l}\text { (1) Potable water: } \\
11,896 \mathrm{~km} \\
\text { network; } 122 \\
\text { reservoirs and } \\
\text { towers [1,579 } \\
\text { ML/day]; } 37 \\
\text { pump stations. (2) } \\
\text { Sanitation: } \\
11,786 \mathrm{~km} \\
\text { network; } 6 \\
\text { Wastewater } \\
\text { Treatment Works } \\
\text { (WWTWs) [1000 } \\
\text { ML/day]. } \\
\text { Additional } \\
\text { capacity from } \\
\text { upgrades and } \\
\text { renewals } 123 \\
\text { ML/day; } 36 \text { pump } \\
\text { stations. }\end{array}$ & $\begin{array}{l}\text { (1) Potable } \\
\text { water: } 10,177 \mathrm{~km} \\
\text { of pipe network, } \\
72 \text { reservoirs, } \\
\text { and } 32 \text { towers } \\
\text { [combined } \\
\text { storage capacity } \\
\text { of } 959 \text { ML (vs } \\
\text { current demand } \\
\text { is } 984 \mathrm{ML} \text { ). (2) } \\
\text { Sanitation: } \\
8,940 \mathrm{~km} \text { of pipe } \\
\text { network, } 17 \\
\text { WWTWs [615 } \\
\text { ML/day, vs } \\
\text { current flow of } \\
714 \mathrm{Ml} / \mathrm{day} \text { ], } 152 \\
\text { pump stations, } \\
169,463 \\
\text { manholes. }\end{array}$ & $\begin{array}{l}\text { (1) Potable water: } \\
\text { 10,506km } \\
\text { network; } 162 \\
\text { reservoirs [1,838 } \\
\text { ML]; } 4 \text { Water } \\
\text { Treatment Plants } \\
\text { [216 ML/day with } \\
\text { adequate to } \\
\text { excellent } \\
\text { performance]; } 36 \\
\text { towers [12.5 ML]; } \\
\text { 210 pump stations. } \\
\text { (2) Sanitation: } \\
\text { 8,095km network; } \\
\text { WWTWs [566 } \\
\text { ML/day]; 78 } \\
\text { pump stations; } \\
\text { 146,150 manholes. }\end{array}$ \\
\hline & $\begin{array}{l}\text { Map of } \\
\text { assets }\end{array}$ & Available. & Available. & lable. \\
\hline & $\begin{array}{l}\text { Asset } \\
\text { condition } \\
\text { assessment }\end{array}$ & $\begin{array}{l}\text { Carried out as per } \\
\text { water and } \\
\text { sanitation master } \\
\text { plan. }\end{array}$ & $\begin{array}{l}\text { Carried out as } \\
\text { per water and } \\
\text { sanitation master } \\
\text { plan. }\end{array}$ & $\begin{array}{l}\text { Planning and } \\
\text { assessment } \\
\text { completed (regular } \\
\text { updates) }\end{array}$ \\
\hline & $\begin{array}{l}\text { Remaining } \\
\text { useful life of } \\
\text { assets }\end{array}$ & $\begin{array}{l}\text { Recorded as per } \\
\text { water and } \\
\text { sanitation } \\
\text { infrastructure } \\
\text { asset management } \\
\text { plan. }\end{array}$ & $\begin{array}{l}46 \% \text { of water and } \\
\text { sanitation } \\
\text { infrastructure is } \\
\text { in an eroded } \\
\text { state, } 53 \% \text { useful } \\
\text { state. }\end{array}$ & $\begin{array}{l}\text { Clearly recorded } \\
\text { as per water and } \\
\text { sanitation master } \\
\text { plan. }\end{array}$ \\
\hline & $\begin{array}{l}\text { Asset } \\
\text { replacement } \\
\text { value }\end{array}$ & $\begin{array}{l}\text { Water and } \\
\text { Sanitation: } \\
\text { ZAR50 bn ( } \$ 3.6 \\
\text { bn) }\end{array}$ & $\begin{array}{l}\text { Water and } \\
\text { Sanitation: } \\
\text { ZAR31 bn ( } \$ 2.2 \\
\text { bn) }\end{array}$ & $\begin{array}{l}\text { Water and } \\
\text { Sanitation: } \\
\text { ZAR39.2 bn ( } \$ 2.8 \\
\text { bn) }\end{array}$ \\
\hline $\begin{array}{l}\text { 2. Level } \\
\text { of } \\
\text { Service } \\
\text { (LoS) }\end{array}$ & $\begin{array}{l}\text { LoS } \\
\text { agreement }\end{array}$ & $\begin{array}{l}\text { World Health } \\
\text { Organisation and } \\
\text { National } \\
\text { standards } \\
\text { followed: Blue } \\
\text { drop and Green } \\
\text { drop status } \\
\text { achieved. }\end{array}$ & $\begin{array}{l}\text { Blue Drop status: } \\
\text { stands at } 96.6 \% \\
\text { 2. Green Drop } \\
\text { status: only } 3 \text { out } \\
\text { of } 17 \text { WWTWs } \\
\text { currently comply. }\end{array}$ & $\begin{array}{l}\text { Blue and Blue } \\
\text { Drop statuses } \\
\text { consistently } \\
\text { improving since } \\
2010 \text {. }\end{array}$ \\
\hline
\end{tabular}


Table 2: Continued.

\begin{tabular}{|c|c|c|c|c|}
\hline \multirow{2}{*}{$\begin{array}{l}\text { IAM } \\
\text { compo- } \\
\text { nent }\end{array}$} & \multirow{2}{*}{$\begin{array}{c}\text { Sub-compo- } \\
\text { nent }\end{array}$} & \multicolumn{3}{|c|}{ Utility and IAM current status } \\
\hline & & Johannesburg & Ekurhuleni & Tshwane \\
\hline $\begin{array}{l}\text { 3. Critical } \\
\text { assets }\end{array}$ & $\begin{array}{l}\text { Criticality } \\
\text { analysis }\end{array}$ & $\begin{array}{l}\text { "Hotspots" } \\
\text { identified and } \\
\text { spatially located } \\
\text { for prioritisation. } \\
\text { 10-year planning } \\
\text { horizon reflected. }\end{array}$ & $\begin{array}{l}\text { Vulnerable assets } \\
\text { clearly indicated } \\
\text { with related } \\
\text { replacement } \\
\text { costs. } 10 \text {-year } \\
\text { planning horizon } \\
\text { reflected. }\end{array}$ & $\begin{array}{l}\text { Criticality } \\
\text { assessment } \\
\text { completed } \\
\text { (regular updates) }\end{array}$ \\
\hline \multirow{4}{*}{$\begin{array}{l}\text { 4. Life } \\
\text { cycle } \\
\text { costing }\end{array}$} & O\&M plan & In place & In place & In place \\
\hline & O\&M skills & $\begin{array}{l}\text { No mention of } \\
\text { skills challenges } \\
\text { in presentations } \\
\text { and reports. }\end{array}$ & $\begin{array}{l}\% \text { Training } \\
\text { budget is }<20 \% \\
\text { - too low; } \\
\text { Vacancy rate } \\
\pm 13 \% \text {; Current } \\
\text { Technical staff } \\
\text { attrition rate is } 2 \\
\text { per month; No } \\
\text { succession plan. }\end{array}$ & $\begin{array}{l}\text { 1. Qualified } \\
\text { operators and } \\
\text { scientists are } \\
\text { scarce and hard } \\
\text { to retain. } \\
\text { 2. Staff at } \\
\text { Rietvlei WTW do } \\
\text { not comply with } \\
\text { Regulation No. } \\
2834 \text { and } 17 .\end{array}$ \\
\hline & $\begin{array}{l}\text { Repair / } \\
\text { replacement } \\
\text { schedule }\end{array}$ & $\begin{array}{l}\text { Infrastructure } \\
\text { Replacement } \\
\text { Plan (IRP) with } \\
\text { timelines is in } \\
\text { place. }\end{array}$ & $\begin{array}{l}\text { Turnaround } \\
\text { Strategy with } \\
\text { timelines being } \\
\text { implemented. }\end{array}$ & $\begin{array}{l}\text { Pipe } \\
\text { Replacement } \\
\text { Master Plan } \\
\text { being } \\
\text { implemented. }\end{array}$ \\
\hline & $\begin{array}{l}\text { Capital } \\
\text { improvemen } \\
\text { t plan (CIP) }\end{array}$ & $\begin{array}{l}\text { Capital } \\
\text { investment } \\
\text { projects being } \\
\text { implemented. } \\
\text { Projects list with } \\
\text { funding sources } \\
\text { in the IDP. }\end{array}$ & $\begin{array}{l}\text { "Quantum Leap } \\
\text { Project" being } \\
\text { implemented } \\
\text { Projects list with } \\
\text { funding sources } \\
\text { in the IDP. }\end{array}$ & $\begin{array}{l}\text { Clearly recorded } \\
\text { in the Master } \\
\text { Plan } \\
\text { Extensive } \\
\text { projects list per } \\
\text { sector } \\
\text { development } \\
\text { plans in the IDP. }\end{array}$ \\
\hline $\begin{array}{l}\text { 5. Long- } \\
\text { term } \\
\text { funding } \\
\text { strategy }\end{array}$ & $\begin{array}{l}\text { 5-year } \\
\text { financial } \\
\text { plan }\end{array}$ & $\begin{array}{l}\text { Financial } \\
\text { planning in } \\
\text { accordance with } \\
\text { National } \\
\text { Treasury's } \\
\text { Medium Term } \\
\text { Revenue and } \\
\text { Expenditure } \\
\text { Framework } \\
\text { (MTREF) } \\
\text { guidelines. }\end{array}$ & $\begin{array}{l}\text { Financial } \\
\text { planning in } \\
\text { accordance with } \\
\text { National } \\
\text { Treasury's } \\
\text { MTREF } \\
\text { guidelines. }\end{array}$ & $\begin{array}{l}\text { Financial } \\
\text { planning in } \\
\text { accordance with } \\
\text { National } \\
\text { Treasury's } \\
\text { MTREF } \\
\text { guidelines. }\end{array}$ \\
\hline
\end{tabular}


Table 2: Continued.

\begin{tabular}{|c|c|c|c|c|}
\hline \multirow{2}{*}{$\begin{array}{l}\text { IAM } \\
\text { compo- } \\
\text { nent }\end{array}$} & \multirow{2}{*}{$\begin{array}{c}\text { Sub-compo- } \\
\text { nent }\end{array}$} & \multicolumn{3}{|c|}{ Utility and IAM current status } \\
\hline & & Johannesburg & Ekurhuleni & Tshwane \\
\hline & $\begin{array}{l}\text { Rate } \\
\text { structure }\end{array}$ & $\begin{array}{l}\text { Tariffs based on } \\
\text { affordability of } \\
\text { services and } \\
\text { competitiveness of } \\
\text { the City and returns } \\
\text { on investments. }\end{array}$ & $\begin{array}{l}\text { Tariffs set at } \\
\text { levels to balance } \\
\text { real cost with } \\
\text { affordability. }\end{array}$ & $\begin{array}{l}2016 / 17 \\
\text { MTREF, all } \\
\text { category's } \\
\text { tariffs are } \\
\text { increased at } \\
10,0 \% \text { from } 1 \\
\text { July } 2016 .\end{array}$ \\
\hline & $\begin{array}{l}\text { Funding } \\
\text { strategy for } \\
\text { repair and } \\
\text { replace } \\
\text { schedule }\end{array}$ & $\begin{array}{l}\mathrm{R} 1.3 \text { bn }(\$ 93 \mathrm{~m}) \\
\text { spent in the past } 3 \\
\text { years on upgrades } \\
\text { and renewal of } \\
\text { WWTWs. Approx. } \\
\text { R1 billion per } \\
\text { annum required to } \\
\text { maintain the IRP. }\end{array}$ & $\begin{array}{l}\text { R4.8 bn }(\$ 342 \mathrm{~m}) \\
\text { allocated for all } \\
\text { upgrading and } \\
\text { renewal projects } \\
\text { in medium term. }\end{array}$ & $\begin{array}{l}45.34 \%, 46.35 \% \\
\text { and } 64.22 \% \text { of } \\
\text { the capital } \\
\text { budget allocated } \\
\text { for the renewals } \\
\text { for the next } 3 \\
\text { years. Legal } \\
\text { minimum is } \\
40 \%\end{array}$ \\
\hline & $\begin{array}{l}\text { Funding } \\
\text { strategy for } \\
\text { CIP }\end{array}$ & $\begin{array}{l}\text { The Cap Invest } \\
\text { Framework is } \\
\text { guided by the } \\
\text { City's obligations } \\
\text { through Chapter 5, } \\
\text { Section 26(i) of the } \\
\text { Municipal Systems } \\
\text { Act (Act } 32 \text { of } \\
2000) \text {. R3.2 bn } \\
\text { (\$229 m) for next } 3 \\
\text { years to Jo'burg } \\
\text { Water. Extensive } \\
\text { projects list per } \\
\text { sector development } \\
\text { plans in the IDP. }\end{array}$ & $\begin{array}{l}\text { Informal } \\
\text { settlement service } \\
\text { delivery backlogs } \\
\text { eradication will } \\
\text { require R286m. } \\
\text { "Quantum Leap } \\
\text { Project" designed } \\
\text { to meet all future } \\
\text { requirements } \\
\text { estimated at } \\
\text { ZAR10 bn ( } \$ 714 \\
\text { m). Extensive } \\
\text { projects list per } \\
\text { sector } \\
\text { development } \\
\text { plans in the IDP. }\end{array}$ & $\begin{array}{l}\text { Only } 25 \% \text { of } \\
\text { required funds } \\
\text { available for } \\
\text { O\&M. } \\
\text { Reprogramming } \\
\text { of upgrades and } \\
\text { expansions due } \\
\text { to budget cuts. } \\
\text { Extensive } \\
\text { projects list per } \\
\text { sector } \\
\text { development } \\
\text { plans in the IDP. }\end{array}$ \\
\hline
\end{tabular}


Table 3: High level IAM assessment outcomes.

\begin{tabular}{|c|c|c|c|c|}
\hline \multirow{2}{*}{ IAM component } & \multirow{2}{*}{ Sub-component } & \multicolumn{3}{|c|}{ Utility and IAM rating } \\
\hline & & Johannesburg & Ekurhuleni & Tshwane \\
\hline \multirow[t]{5}{*}{ 1. Asset inventory } & List & Good & Good & Good \\
\hline & Map & Good & Good & Good \\
\hline & Condition assess & Good & Good & Good \\
\hline & Remaining life & Good & Good & Good \\
\hline & Asset repl. value & Good & Good & Good \\
\hline $\begin{array}{l}\text { 2. Level of } \\
\text { service }\end{array}$ & LoS agreement & Good & Fair & Fair \\
\hline 3. Critical assets & Criticality analysis & Good & Good. & Good \\
\hline \multirow{4}{*}{$\begin{array}{l}\text { 4. Life cycle } \\
\text { costing }\end{array}$} & O\&M plan & Good & Good & Good \\
\hline & O\&M skills & Good & Fair & Good \\
\hline & Repair / replace & Good & Fair & Fair \\
\hline & Capital improvement plan & Good & Good & Good \\
\hline \multirow{4}{*}{$\begin{array}{l}\text { 5. Long-term } \\
\text { funding strategy }\end{array}$} & 5-year financial plan & Good & Good & Good \\
\hline & \begin{tabular}{|l|} 
Rate structure \\
\end{tabular} & Good & Good & Good \\
\hline & Repair and replace & Good & Good & Good \\
\hline & Capital improvement plan & Good & Fair & Fair \\
\hline \multicolumn{2}{|l|}{ Overall rating } & Good & $\begin{array}{c}\text { Fair to } \\
\text { Good }\end{array}$ & $\begin{array}{c}\text { Fair to } \\
\text { Good }\end{array}$ \\
\hline \multicolumn{5}{|c|}{  } \\
\hline
\end{tabular}

Tactical and operational level assessment of the IAM practices in the three utilities is summarised below.

- Asset inventory: All three utilities had comprehensive asset registers, with maps, condition assessment records, remaining useful lives and asset replacement values for their respective infrastructure.

- Level of service: The drinking water quality and effluent quality standards are set by national regulation and any customer expectations or needs are captured during public consultations and recorded in the IDP on an annual basis. The IDP is required by legislation to be approved by the City Council each year. From the available information it seems that Johannesburg has got very little if any risk of breaching the LoS agreement. Ekurhuleni is at risk for three reasons: 1) Water demand exceeds reservoir storage capacities and the WWTWs capacities are exceeded. New developments are now hampered because of this situation, 2) Funding shortages will delay the renewal and / or development programmes, 3) Unstable skills base and lack of succession planning. Tshwane risks not meeting the standards mainly because of funding shortages $(25 \%$ of the required funds for infrastructure renewal is available. Otherwise their rating in terms of water and effluent quality has been consistently improving.

- Critical assets: All three utilities have detailed records of critical or vulnerable assets. 
- Lifecycle costs: Johannesburg is good. Although Ekurhuleni and Tshwane have very good plans, they are at risk due to the skills and funding challenges are at risk due to skills and funding shortages. It must be stated though that Tshwane's situation might not be as severe as Ekurhuleni's when it comes to the skills.

- $\quad$ Long-term funding strategy: Johannesburg is good. Ekurhuleni and Tshwane are at risk because of funding shortages leading to budget cuts.

\section{CONCLUSION AND RECOMMENDATIONS}

From the results of this study it is clear that the three utilities, which form the economic hub of the country, have efficient and effective IAM strategies and plans in place and they are complying with relevant legislation and regulations. However, they are facing a number of challenges for which they will require innovative solutions in order to continue to fulfil their mandates going forward.

Suggested solutions to the key challenges could include the following:

- Technical skills: It is common knowledge that the most precious asset any organisation can have are its people. Although the problem of skills shortage would not normally be severe in metropolitan areas, it is important that the utilities develop and maintain sound human capital development strategies to attract and retain technical skills. Ekurhuleni in particular needs to allocate sufficient budgets towards skills development within the organisation, especially specialised and scares skills that are required for the operation and maintenance of water and wastewater treatment plants.

- Funding challenges: The recurring theme in most municipalities is the shortage of funds for new developments and especially for the renewal, upgrading and / or replacement of existing ageing infrastructure. A focus on water conservation and demand management is one area where operational revenue could be augmented. Investing in initiatives like leak eradication and preventing illegal connections through community awareness campaigns could yield good returns.

This was an interesting exercise and it is hoped that it will add to the knowledge regarding the importance of IAM to ensure that all infrastructure is optimally operated and maintained to benefit current and future residents.

\section{REFERENCES}

[1] Statistics South Africa, Community Survey Statistics, Jun. 2016. http://cs2016.statssa.gov.za. Accessed on: 15 Sep. 2016.

[2] Republic of South Africa, Water services infrastructure asset management strategy. Water Services: Policy and Strategy, Department of Water Affairs: Pretoria, 2011.

[3] Alegre, A. \& Coelho S.T., Infrastructure asset management of urban water systems (chapter 3). Water Supply System Analysis - Selected Topics, ed. A. Ostfeld, InTech, pp. 49-73, 2012.

[4] Burns, P., Hope, D. \& Roorda, J., Managing infrastructure for the next generation. Automation in Construction, 8(6), pp. 689-703, 1999.

[5] United States Environmental Protection Agency (US EPA), Condition Assessment Technologies for Water Transmission and Distribution Systems, Publication No. EPA/600/R-12/017, 2012. 
[6] United Kingdom Water Industry Research (UKWIR), A Common Framework for Capital Investment Planning, UK Water Industry Research, Reino Unido, Regulatory Report No. 02/RG/05/3 (4 vols.), 2003.

[7] Alegre, H. \& Almeida, M.C. eds, Strategic Asset Management of Water and Wastewater Infrastructures, IWA Publishing, 536 pp., 2009.

[8] Republic of South Africa, Water services infrastructure asset management strategy study. Phase 2A: Action plan. Proceeding from fact-finding to solution-identification, Department of Water Affairs: Pretoria, 2006.

[9] New Mexico Environmental Finance Centre, Asset Management: A Guide for Water and Wastewater Systems, 2006.

[10] City of Johannesburg, 2016/21 Integrated Development Plan, Johannesburg, 2016.

[11] Ekurhuleni Metropolitan Municipality, Integrated Development Plan 2016/17 to 2018/19, Germiston, 2016.

[12] City of Tshwane, Integrated Development Plan 2016/21, Tshwane, 2016. 